\title{
Rainfall-runoff modelling of ephemeral streams in the Valencia region (eastern Spain)
}

\author{
Ana M. Camarasa ${ }^{1 *}$ and Kevin A. Tilford ${ }^{2 \dagger}$ \\ ${ }^{1}$ Department of Geography, University of Valencia, Ap. 22060, 46080 Valencia, Spain \\ 2 Water Department of WS Atkins Consultants Ltd, Birchwood Boulevard. Birchwood, Warrington WA3 7WA, UK
}

\begin{abstract}
:
This paper presents preliminary results from the application of a transfer-function rainfall-runoff model to ephemeral streams in Mediterranean Spain. Flow simulations have been conducted for two small catchments (Carraixet and Poyo basins), located in close proximity to one another yet with significantly different geological characteristics. Analysis of flow simulations for a number of high-flow events has revealed the dominant influence of the rainfall on the catchment response, particularly for high-rainfall events. Particular success has been attained modelling the highest magnitude events in both catchments and for all events in the faster responding (Poyo) catchment. In order to investigate the viability of the model for forecasting floods in ungauged catchments, additional investigations have been conducted by calibrating the model for one catchment (donor catchment) and then applying it to another (receptor catchment). The results indicate that this can be successful when either the donor catchment is a fast response catchment or when the model is calibrated using a high-magnitude event in the donor catchment, providing that the modelled receptor catchment event is of a lower magnitude. Copyright (c) 2002 John Wiley \& Sons, Ltd.

KEY WORDS ephemeral stream; transfer-function; rainfall-runoff model; simulation; donor catchment; receptor catchment; ungauged catchment; hydrograph; flood
\end{abstract}

\section{INTRODUCTION: RAINFALL-RUNOFF CONVERSION IN EPHEMERAL STREAMS}

The drainage basin plays a fundamental role in any hydrological study of processes concerning the conversion of rainfall to runoff. The catchment can be considered as a system that responds to certain inputs, the principal one being precipitation, and converting them into outputs, such as river flow and sediment movement. During this conversion process, the basin attempts to adapt its form to the system's energy conditions, in an attempt to reach geomorphological equilibrium (Morisawa, 1985).

The influence of drainage basin morphology and dynamics on catchment hydrographs is simulated, to a greater or lesser extent, in all rainfall-runoff conversion models, from the physically based models, which operate at a detailed scale, to the empirical, and black-box, models. In the former, the presence of the catchment is clearly apparent, because the model attempts to imitate each hydrological process, based on the laws of conservation of mass, energy and momentum. Many researchers make use of geographical information systems (GISs) for hydrological studies, applying distributed models, which operate at a pixel level (Maidment, 1993). In contrast, black-box models utilize a statistical transfer function to relate the system inputs and outputs. This function should, in principle, reflect the implicit influence of the underlying physical system, where rainfall-runoff conversion occurs (Klemes, 1981).

Although the influence of the catchment on the rainfall-runoff conversion process is evident, the way in which its influence takes effect depends on the type of fluvial system and, consequently, on the dominant

* Correspondence to: Ana M. Camarasa, Department of Geography, University of Valencia, Ap. 22060, 46080 Valencia, Spain.

E-mail: ana.camarasa@uv.es

${ }^{\dagger}$ Formerly Lecturer at the Telford Institute of Environmental Systems, University of Salford. 
discharge regime. According to Graf (1988) 'processes control forms in high magnitude events, while forms control processes in low magnitude events'. The fluvial systems of humid regions respond to high-frequency low-energy events with a preponderance of throughflow. Consequently, basins have a marked influence in the rainfall-runoff conversion process. However, in the case of Mediterranean and semi-arid systems, the dominant events occur infrequently, but with high magnitude. In these systems surface-runoff predominates during floods, and the influence of the basin is reduced substantially and the influence of rainfall increases markedly. In fact, the most notable hydrological characteristic of Mediterranean ephemeral streams is that channels remain dry for most of the year, because they are unconnected to aquifers and therefore lack baseflow (Mateu, 1988; Segura, 1990). Quickflow depends almost exclusively on the rainfall, and often is related to intense 'high-energy' rainfall, leading to flash floods (Segura and Camarasa, 1996).

The speed of the processes and the importance of high intensity rainfall have meant that, historically, simple models, very dependent upon precipitation, such as the unit hydrograph, have worked adequately for predicting flood hydrographs in this environment (Marco, 1989; Abdulrazzak, 1989; García Bartual and Marco, 1990). Even when more advanced unit hydrographs have been used, such as the geomorphological unit hydrograph (GUH) (Rodriguez-Iturbe and Valdés, 1979; Rodriguez-Iturbe et al., 1982; Corradini et al., 1986; Rosso and Caroni, 1987; Nouh, 1990), incorporating morphometric catchment indicators, the results have demonstrated the importance of the scale parameter-related to the catchment's rate of response and the rainfall intensity - compared with the form parameter - related to the geomorphology of the basin (Corradini et al., 1986; Camarasa, 1995).

Thus, from the point of view of extrapolating rainfall-runoff models from gauged to ungauged basins, the distinction between high- and low-magnitude events, or between fast and slow catchment responses, could be more significant than the different geomorphological features between basins (always assuming that the reference frame relates to the same morphoclimatic context). The magnitude and the internal structure of inputs, together with the implicit type of lumped catchment reaction, could become the main variables to take into account for hydrograph modelling. This observation could have very interesting implications for real-time catastrophic flood forecasting, using mathematical simulations. Within the context of a region with similar characteristics, it could mean significant saving in simulation models for gauged catchments and a valid tool for hydrograph prediction in ungauged basins.

This paper shows the preliminary results of the application to Mediterranean basins of a simple rainfall-runoff conversion model (transfer-function model-TFM), developed at the University of Salford (England) for flood hydrograph simulation in humid regions. This model, which is strongly dependent on the rainfall structure, was applied to several flood events, in two Valencian ephemeral streams: the Barranc de Carraixet River $\left(128 \mathrm{~km}^{2}\right)$ and the Rambla de Poyo River $\left(187 \mathrm{~km}^{2}\right)$. The model's extrapolation capability was tested in both temporal (extrapolations between different events in the same basin) and spatial dimensions (extrapolating from one basin to another).

\section{DESCRIPTION OF RIVER CATCHMENTS}

Mediterranean 'ramblas' and 'barrancos' are fluvial systems with ephemeral streams, where basins have steep slopes, scarce vegetation and poorly developed soils. They frequently occur over a substrate composed of permeable materials (limestones and dolomites), and are geomorphologically complex, which is strongly influenced by underlying geological structures as a consequence of germanic $\bullet$ relief, formed by distensive forces, during the Alpine Orogeny. The drainage networks are, in many cases, still not fully organized, owing to the low frequency of events with sufficient energy to affect the geomorphology. Both the basins studied, the Barranc del Carraixet and la Rambla de Poyo (Figure 1), located in the eastern section of the Iberica Range (east of Spain), belong to this morphoclimatic environment.

The first basin used in this study is the drainage area of a gauged sub-basin $\left(128 \mathrm{~km}^{2}\right)$ belonging to the Barranc de Carraixet basin $\left(311 \mathrm{~km}^{2}\right)$. The stream flows into the Mediterranean Sea north of Valencia, Spain's 


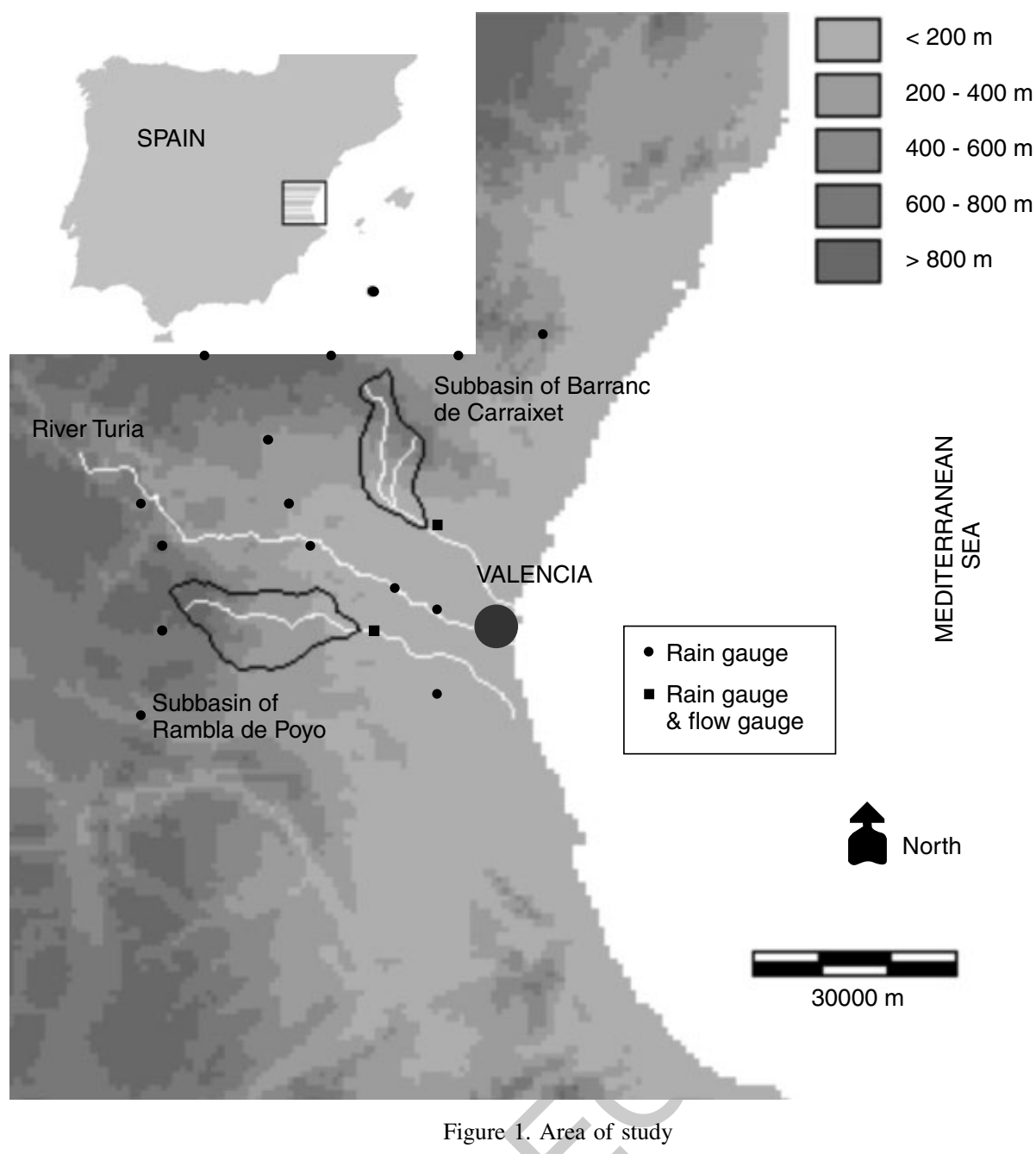

third largest city, so the catchment includes areas of intensive land use. The catchment has an elongated and asymmetrical shape (elongation rate of 0.33), marked relief (over 36\% of the area has slopes steeper than $30 \%$ ), and is strongly influenced by underlying geological structures.

The geomorphology of the basin is very varied (Camarasa, 1995). Three main sectors can be differentiated: the headwaters, an intermediate area of alluvial fans and a calcareous subtabular platform.

1. The headwaters are in the mountainous area formed by highly resistant mesozoic materials (limestone, dolomites and sandstone). It has a typical germanic •relief: highly faulted and very steep. The upper Q1 catchment has high permeability.

2. The middle catchment consists of a series of deep alluvial fans and piedmonts formed during several Quaternary phases, overlying a faulted and sunken Pliocene graben.

3. A calcareous subtabular platform borders the south of the middle basin.

The Rambla de Poyo drains the area south of Valencia city, between the basins of the rivers Turia and Jucar, and flows into the Albufera de Valencia (a coastal lagoon). The gauged sub-basin has three principal tributaries: the Barranco Grande, the Barrranco de la Cueva Morica and the Rambla de Gallo-Chiva. 
Geomorphologically it can be divided into three units, showing a similar configuration to those of the Barranc de Carraixet.

1. Mountainous headwaters, developed over resistant limestone-dolomitic materials, forming steep relief.

2. An intermediate sector overlying a sunken graben, where large-scale alluvial fans mark the contact between the Mesozoic headwaters and the graben.

3. An eastern sector, with subtabular relief, made up of highly fragmented clay-mudstones.

The fifth-order drainage network is fairly disorganized, with an elongation ratio of 0.4.

The main difference between both basins is the permeability: Rambla de Poyo has a greater proportion of underlying impermeable rocks (35\%), compared with Barranc de Carraixet (3\%). Consequently, for the same inputs, the Rambla de Poyo has a faster response rate than Barranc de Carraixet. For similar storm events, the average response lag-time for the Poyo basin is $3 \mathrm{~h}$, compared with $5 \mathrm{~h}$ for the Carraixet. The average quickflow velocity is $2.3 \mathrm{~m} \mathrm{~s}^{-1}$ in the Poyo catchment compared with $0.5 \mathrm{~m} \mathrm{~s}^{-1}$ in the Carraixet (Camarasa, 1995).

\section{FLOOD EVENT DATA}

Although in Spain the most dangerous floods occur in a few hours, the national hydrological network provides data only every day. As a consequence, processes are measured with an incorrect time interval. Studies based on daily data are not precise enough to understand the formation of flash floods and, therefore, forecasting hydrographs for small semi-arid basins is a highly difficult task.

Some important flood events, which affected the Mediterranean region during 1982 and the north coast during 1983, led the government to adopt some structural measures for flood prediction. A new hydrological network Sistema Automático de Información Hidrológica (SAIH ; automatic system of hydrological information) is being installed by the main hydrographic authorities, starting with those areas where flood risk is more important. Thus, the River Jucar Hydrographic Authority has been the first to produce reliable hydrological data every 5 min.

This investigation is supported by rainfall (17 rain gauges) and river flow (two gauges) data provided for this hydrographic authority, for three flood events occurring on 11-12 November 1988, 8-9 September 1990 and 16-17 April 1991. Owing to the geographical proximity of the two catchments they were affected simultaneously by the same storms, enabling effective comparisons to be made between the two for the same events. The two autumnal events (November 1988 and September 1990) were of higher magnitude than that in April 1990 (Table I).

\section{FLOOD HYDROGRAPH SIMULATION USING A SIMPLE RAINFALL-RUNOFF TRANSFER MODEL}

A wide range of lumped rainfall-runoff forecasting models (models that simulate river flow using a single rainfall input taken to be representative of rainfall across the entire catchment) have been developed. O'Connell and Clark (1981) and Reed (1984) provide reviews of many of these. These include conventional methods such as the unit hydrograph (Chander and Shanker, 1984), S-curve, Clark method, linear cascade reservoir model, conceptual models and non-linear storage models (Bobinski and Mierkiewicz, 1986; Corradini et al., 1986; Corradini and Melone, 1987).

The hydrograph simulation model used in this work consisted of a simple rainfall-runoff transfer function that has been developed at the University of Salford by Dr Tilford and his co-workers.

Rainfall-runoff models are widely used for predicting flood hydrographs because they have a simple mathematical structure and often are relatively easy to use. Within this class of models the most conventional and most widely used is the unit hydrograph, an approach first presented by Sherman (1932) and later 
Table I. Flood event characteristics

\begin{tabular}{|c|c|c|c|c|}
\hline \multirow[t]{2}{*}{ Basin } & \multirow{2}{*}{$\begin{array}{l}\text { Hydrological } \\
\text { features }\end{array}$} & \multicolumn{3}{|c|}{ Events } \\
\hline & & November 1988 & September $1990^{a}$ & April 1991 \\
\hline \multirow[t]{10}{*}{ Barranc de Carraixet } & Total rainfall $(\mathrm{mm})$ & $72 \cdot 8$ & $152 \cdot 7$ & $23 \cdot 9$ \\
\hline & Net rainfall $(\mathrm{mm})$ & 5.4 & 9.9 & 1.4 \\
\hline & Runoff threshold (mm) & 38 & 83 & $13 \cdot 5$ \\
\hline & Runoff coefficient $(\%)$ & 7 & $5 \cdot 6$ & $5 \cdot 5$ \\
\hline & Runoff deficit $\left(10^{6} \mathrm{~m}^{3}\right)$ & $8 \cdot 6$ & 18 & $2 \cdot 89$ \\
\hline & Total flood runoff $\left(10^{6} \mathrm{~m}^{3}\right)$ & $0 \cdot 69$ & $1 \cdot 27$ & $0 \cdot 17$ \\
\hline & Peak discharge $\left(\mathrm{m}^{3} \mathrm{~s}^{-1}\right)$ & 21.7 & $73 \cdot 55$ & $9 \cdot 5$ \\
\hline & Lag time & $6 \mathrm{~h} 5 \min$ & $3 \mathrm{~h} 15 \mathrm{~min}$ & $5 \mathrm{~h} 55 \mathrm{~min}$ \\
\hline & Time to peak & $1 \mathrm{~h} 55 \min$ & $1 \mathrm{~h} 40 \mathrm{~min}$ & $1 \mathrm{~h} 25 \mathrm{~min}$ \\
\hline & Stream velocity $\left(\mathrm{m} \mathrm{s}^{-1}\right)$ & $0 \cdot 38$ & 0.72 & 0.39 \\
\hline \multirow[t]{10}{*}{ Rambla de Poyo } & Total rainfall & $74 \cdot 8$ & 71.9 & $18 \cdot 8$ \\
\hline & Net rainfall & 6 & 0.5 & $2 \cdot 4$ \\
\hline & Runoff threshold (mm) & 38 & 59.7 & $7 \cdot 9$ \\
\hline & Runoff coefficient $(\%)$ & 8 & 0.7 & 12 \\
\hline & Runoff deficit $\left(10^{6} \mathrm{~m}^{3}\right)$ & $12 \cdot 7$ & $13 \cdot 2$ & $3 \cdot 04$ \\
\hline & Total flood runoff $\left(10^{6} \mathrm{~m}^{3}\right)$ & $1 \cdot 2$ & 0.09 & 0.44 \\
\hline & Peak discharge $\left(\mathrm{m}^{3} \mathrm{~s}^{-1}\right)$ & 193 & $65 \cdot 35$ & 29.5 \\
\hline & Lag time & $1 \mathrm{~h} 50 \mathrm{~min}$ & $4 \mathrm{~h} 10 \mathrm{~min}$ & $3 \mathrm{~h} 10 \mathrm{~min}$ \\
\hline & Time to peak & $15 \min$ & $30 \min$ & $55 \min$ \\
\hline & Stream velocity $\left(\mathrm{m} \mathrm{s}^{-1}\right)$ & 3 & & 1.8 \\
\hline
\end{tabular}

${ }^{\text {a }}$ September event in Rambla de Poyo has not been used for simulation because quality of hydrological data is inadequate.

developed in different versions by many authors (e.g. Nash, 1958; Rodriguez-Iturbe and Valdés, 1979; Gupta and Gaymire, 1983; Rosso, 1984; Corradini et al., 1986).

The transfer-function model (TFM) described by Box and Jenkins (1976) is a relatively recent alternative to unit hydrographs. Although originally developed for control applications in electrical engineering, transfer functions present a number of characteristics that make them appropriate for river flow modelling, including: (i) structural simplicity; (ii) parametric efficiency ('parsimony'); (iii) self-correcting capacity; and (iv) potential for incorporating parameter updating.

In recent years a number of researchers have reported attempts to simulate the rainfall-runoff process at catchment scale using such models in temperate humid environments (e.g. Moore and O'Connell, 1978; Moore, 1980; Cluckie, 1993; Jakeman and Hornberger, 1993; Young and Beven, 1994; Nalbantis, 1995; Ramos et al., 1995). Indeed, developments have been such that transfer-function rainfall-runoff models are used routinely for operational flow forecasting in several regions of the UK: in the southwest region (Birks et al., 1989; Aucott et al, 1992); on the River Irwell in the northwest (Cluckie and Owens, 1987); in eastern England on the River Cam and Willow Brook (Tilford, 1993). They also have been developed for real-time flood-flow modelling (e.g. Cluckie et al., 1989: Wilke and Barth, 1991; Lees et al., 1994; Lees, 1997). The particular characteristics of rainfall-runoff conversion processes in semi-arid environments suggest that, because of the dependence of the hydrograph on intense rainfall, this model might be applied successfully to Mediterranean basins during flood events.

\section{The transfer-function rainfall-runoff model}

Transfer-function rainfall-runoff models (TFMs) forecast future hydrographs using measurements of current and previously observed rainfall and flows. Powell (1985) and Owens (1986) demonstrated that the rainfall-runoff transformation process could be simulated satisfactorily by a single-input-single-output 
(SISO) transfer function with the following structure•

$$
\hat{Q}_{t}=a_{1} Q_{t-1}+a_{2} Q_{t-2}+\cdots a_{p} Q_{t-p}+b_{0} R_{t-\tau}+b_{1} R_{t-1-\tau}+\cdots b_{q} R_{t-q-\tau}
$$

where $\hat{Q}_{t}$ is the forecast flow for time $t, Q_{t}$ and $R_{t}$ are the observed flow and rainfall respectively at time $t, \tau$ is a pure time delay, and $a$ and $b$ are rainfall and flow parameters respectively. The time between successive rainfall and flow observations, i.e. the time between $t$ and $t+1$ defines the model time interval $\Im$.

A key feature of the model structure described by Equation (1) is the use of past observed flow values to correct the model forecasts via a closed (feedback) loop. This self-correction capability provides robustness to the model when operated in a forecasting mode because forecasts of future flow are dependent upon past observed values.

The rainfall input $R_{t}$ can be defined as total or effective rainfall. When effective rainfall is used the TFM is, to a certain extent, equivalent to the unit hydrograph (Jakeman and Hornberber, 1993), albeit more efficient (or 'parsimonious') parametrically. When total rainfall is used, a factor is used to scale the rainfall input. In accordance with the model output (i.e. runoff) in order to maintain a mass balance. The scaling factor $\Delta$ is applied according to Equation (2)

$$
\hat{Q}_{t}=a_{1} Q_{t-1}+a_{2} Q_{t-2}+\cdots a_{p} Q_{t-p}+\Delta_{t}\left(b_{0} R_{t-\tau}+b_{1} R_{t-1-\tau}+\cdots b_{q} R_{t-q-\tau}\right)
$$

$\Delta_{t}$ being updated through the course of an event, according to

$$
\Delta_{t}=\mu \Delta_{t-1}+(1-\mu)\left[\frac{y_{t}-\left(a_{1} y_{t-1}+\cdots+a_{p} y_{t-p}\right)}{b_{1} u_{t-1}+\cdots+b_{q} u_{t-q}}\right]
$$

The pure time delay $\tau$ enables the model to simulate flow in catchments where: (i) rainfall is consistently confined to an area of the catchment upstream of the gauging station (e.g. see O'Connell and Clarke, 1981) and/or (ii) where initial losses are large (i.e. as a surrogate for initial storage). The second is especially relevant when modelling highly permeable catchments, and, together with the model's flexibility for simulating hydrographs in environments where the river flow is highly dependent on the rainfall, was the prime reason for the application of this model to ephemeral streams in Mediterranean Spain.

\section{Specification and calibration of the transfer function model}

The TFM relates total rainfall to runoff by an empirically derived input-output relationship determined by off-line calibration. This calibration process consists of three stages: determination of optimal model interval; determination of optimal model structure; and parameter estimation. Model structure, order and interval are interrelated. The model order is defined as the total number of parameters in the model. Structure is defined as the number of $a$ parameters, $b$ parameters and time delay $\tau$. Finally, the model interval is the time interval that the model uses during operation (which may be equal to or greater than the data interval).

Model order determination (structure identification) aims to identify the optimal model structure, i.e. the structure combining the attributes of parsimony and forecasting accuracy. The optimal model will have sufficient parameters to describe catchment response adequately while avoiding overparameterization. In addition to the fact that it is unrealistic to estimate a large number of model parameters from a limited (and noisy) data set, parsimony is also desirable because the model structure influences computational (run) time and the number of past data required for forecasting.

Determination of optimal structure is linked intrinsically to the selection of model time interval and, by definition, the optimal model structure can be identified only if the optimal model interval has been ascertained. Failure to identify the optimal model interval will result in suboptimal forecasting performance. Small model interval will necessitate an increased number of parameters and a potentially poorer model performance (owing to superfluous additional information), whereas a larger interval will result in fewer parameters and poorer performance (owing to significant information being lost or missed). In the rainfall-runoff process the optimal 
model interval is governed jointly by catchment response dynamics and the characteristics of the rainfall field, and consequently will vary from catchment to catchment and from event to event.

The model (time) interval $\Im$ is determined prior to parameter estimation by using an objective technique first proposed for the identification of digital control systems by Isermann (1981) and developed for rainfall-runoff models by Powell and Cluckie (1984). Powell (1985) showed that the step response of a system (i.e. the integral of the impulse response) could be used to determine the optimal time interval $\Im_{\text {opt }}$ by the following rule

$$
\frac{T_{90}}{2}<\Im_{\text {opt }}<\frac{T_{90}}{10}
$$

where $T_{90}$ is the time for the system to rise to $90 \%$ of the steady state output as determined from the step response.

Once the model interval has been defined, the model structure can be determined, i.e. the number of rainfall and flow parameters ( $p$ and $q$ respectively). Several methods for the determination of model structure exist. For this study, an equal-order model search technique developed by Owens (1986) has been adopted by virtue of simplicity and ease of use. In the search, parameters are estimated sequentially for equal-order models (i.e. $p=q$ ) from a 2,2 model structure upwards, until an increase in model order no longer results in a significant improvement in model accuracy.

The following evaluation criteria are used: (i) error statistics for the model convolution of the calibration data; (ii) model impulse response (physically viable, i.e. positive and stable); (iii) parameter redundancy, i.e. an unnecessarily high (overspecified) model order.

For rural catchments in the UK experience has shown that if the model interval is identified correctly, process rarely has to be repeated beyond a 6,6 structure, with most catchments being modelled adequately with a model order less than eight. Model instability (e.g. to a unit pulse input) usually signifies overparameterization. Once the optimal equal-order model has been found the number of $a$ parameters is reduced until an increase in modelling error arises.

Harpin (1982) conducted a detailed analysis of the relative performance of a range of 'conventional' recursive parameter estimation algorithms. He concluded that the ordinary recursive least squares (ORLS) linear estimator provided satisfactory convergence to the final (optimal) parameter values, was inherently stable and robust, and was satisfactory for hydrological modelling (see also Cluckie and Harpin, 1982: Cluckie et al., 1980). The algorithm sequentially steps through the rainfall and flow data pairs, progressively updating the parameter estimates, attempting to minimize the squares of the one-step-ahead forecast errors.

Model identification/calibration produces a model that exhibits a generalized response. Assuming calibration has been performed adequately, the model will have a percentage runoff closely corresponding to the average percentage runoff of the rainfall/runoff calibration time-series. As the number of events used for calibration increases, the model's ability to produce high-accuracy forecasts on average increases, although its performance in less typical flood conditions (i.e. those where the antecedent catchment condition or the rainfall profile, distribution or intensity departs significantly from the 'norm') deteriorates.

\section{Application of the transfer function model}

In this study TFM was first applied to each event in each catchment separately, with the aim of checking its ability to simulate the observed event hydrographs. The TFM model parameters were calibrated for two system inputs: total rainfall and effective (net) rainfall.

For the first case, the catchment average total rainfall was calculated from the rain-gauge data using Thiessen polygons (the calibration of the model implicitly accounting for losses, through the parameter estimation).

For the second case, the effective rainfall was estimated, before applying the TFM, from the total rainfall using the US Soil Conservation Service (SCS) empirical loss model method (US Soil Conservation Service, 1972) adapted to Spanish conditions by Témez (1978). This approach has been successfully used in a variety of 
applications in Mediterranean catchments (Camarasa and Garcia Bartual, 1991; Camarasa, 1995). According to this method all the rainfall at the start of the storm is lost (through evapotranspiration and infiltration). Surface runoff commences only once a threshold soil absorption level $\left(P_{0}\right)$ is reached, as defined by the following expression

$$
\begin{aligned}
& \sum E=0 \text { for } \sum P \leq P_{0} \\
& \sum E=\frac{\left(\sum P-P_{0}\right)^{2}}{\sum P+4 P_{0}} \text { for } \sum P>P_{0}
\end{aligned}
$$

where $\sum P$ is the accumulated rainfall from the beginning of the storm, $\sum E$ is runoff or effective rainfall and $P_{0}$ is the runoff threshold.

Although $P_{0}$ can be estimated from catchment slope, soil characteristics and land use, in this study $P_{0}$ was estimated from the runoff coefficient, $C$, which is defined after Camarasa and Garcia-Bartual (1991) as

$$
C=\frac{\sum E}{\sum P}=\frac{\left(\sum P-P_{0}\right)^{2}}{\left(\sum P+4 P_{0}\right) \sum P}
$$

The model was applied using a model time interval of $15 \mathrm{~min}$. The results of the event simulations undertaken (Table II) illustrate:

1. A model input of effective rainfall produced much better simulations than for total rainfall. The tests demonstrate the applicability of the SCS losses method. For example, for the same catchment (Rambla de Poyo) and the same event (November 1988) the results were much better using net rainfall (1, 5 order model and 9.97 RMS) than using total rainfall (30, 30 order model and 33.27 RMS).

2. The model's ability to reproduce the shape of the total hydrograph in 'high energy' events and/or in the faster response catchment (i.e. the Rambla de Poyo). In contrast, the TFM was unsuccessful in simulating

\begin{tabular}{|c|c|c|c|c|c|c|c|}
\hline \multirow[t]{2}{*}{ Basin } & \multirow[t]{2}{*}{ Event } & \multirow[t]{2}{*}{ Input } & \multirow{2}{*}{$\begin{array}{l}\text { Model structure } \\
\text { (number of } \\
\text { parameters } \\
a \text { and } b \text { ) }\end{array}$} & \multirow{2}{*}{$\begin{array}{l}\text { Time delay, } \\
\tau(\min )\end{array}$} & \multicolumn{3}{|c|}{ Error analysis } \\
\hline & & & & & $\begin{array}{l}\text { Mean } \\
\text { error }\end{array}$ & $\begin{array}{l}\text { Root mean } \\
\text { square } \\
\text { (RMS) error }\end{array}$ & $\begin{array}{c}\text { RMS of } \\
\text { model } \\
\text { convolution }\end{array}$ \\
\hline \multirow[t]{6}{*}{$\begin{array}{l}\text { Barranc de } \\
\text { Carraixet }\end{array}$} & $\begin{array}{c}\text { November } \\
1988\end{array}$ & Total rainfall & 3,5 & 30 & -0.015 & 0.924 & $5 \cdot 11$ \\
\hline & & Net rainfall & 5,5 & 30 & 0.003 & 0.877 & 2.79 \\
\hline & $\begin{array}{c}\text { September } \\
1990\end{array}$ & Total rainfall & 1,5 & 0 & -0.053 & $2 \cdot 318$ & $3 \cdot 85$ \\
\hline & & Net rainfall & 1,5 & 0 & $-0 \cdot 12$ & 1.558 & $2 \cdot 77$ \\
\hline & April 1991 & Total rainfall & 1,6 & 150 & -0.029 & 0.763 & 3.43 \\
\hline & & Net rainfall & 1,6 & 150 & -0.002 & 0.752 & $2 \cdot 89$ \\
\hline \multirow[t]{4}{*}{$\begin{array}{l}\text { Rambla de } \\
\text { Poyo }\end{array}$} & $\begin{array}{c}\text { November } \\
1988\end{array}$ & Total rainfall & 30,30 & 0 & $0 \cdot 357$ & $10 \cdot 18$ & $33 \cdot 27$ \\
\hline & & Net rainfall & 1,5 & 0 & 0.207 & 5.95 & 9.97 \\
\hline & April 1991 & Total rainfall & 1,6 & 0 & -0.053 & 1.811 & $2 \cdot 69$ \\
\hline & & Net rainfall & 1,2 & 0 & 0.008 & $1 \cdot 547$ & $2 \cdot 56$ \\
\hline
\end{tabular}
smaller flood flows in the slower response catchment (i.e. the Barranc de Carraixet).

Table II. Results of transfer-function model calibration 


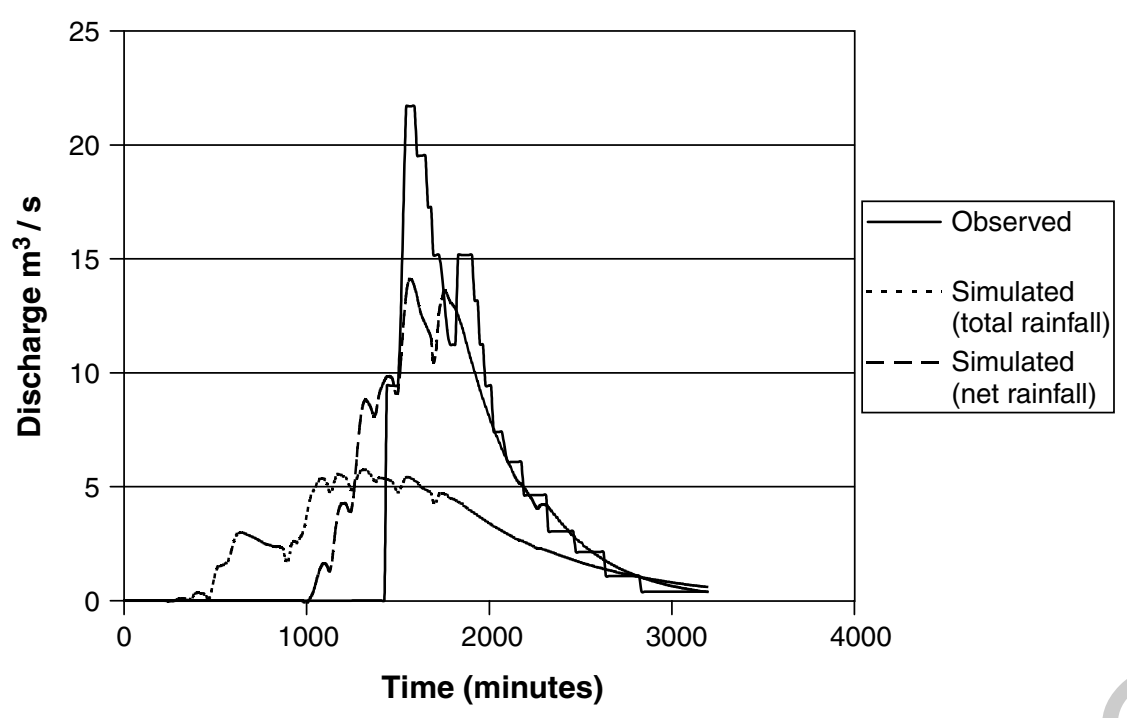

Figure 2. Comparison between simulations carried on with total and net rainfall inputs (Carraixet, November 1988 event). Error in peak estimation: using total rainfall- $73.7 \%$ in peak discharge and 225 min out of phase; using net rainfall-35\% in peak discharge and 30 min out of phase

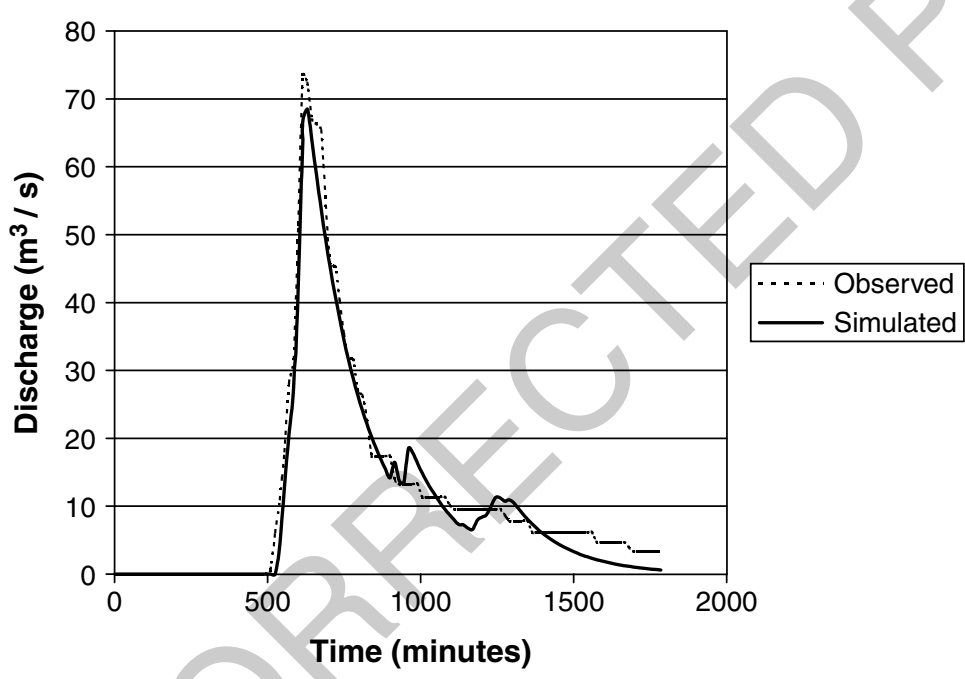

Figure 3. Simulation of a high-magnitude event (Carraixet, September 1990 event). Error in peak estimation: 6.8\% in peak discharge and 15 min out of phase

Figure 2 shows an example of the improved simulations arising from the use of (SCS) effective rainfall compared with those using total rainfall. It is worth noting that, although the catchment characteristics may be of secondary importance for very high magnitude events, their influence was still significant in two key aspects: (i) the high volume of losses to the subsurface flow (Segura and Camarasa, 1996), and the tendency to form flash floods, with moving wave fronts, as a result of the rapid concentration of flows moving down a dry river bed. (Woolhiser, 1971). For these reasons, when the catchment response was immediate, either because it was a fast-response catchment, as in the case of the Rambla de Poyo, or because of high intensity rainfall (as in the case of the Carraixet September 1990 event (Figure 3), or the Poyo November 1988 event), 
the TFMs produced excellent simulations. However, when low-energy events in slow-response catchments were considered (e.g. the Carraixet April 1991 event), model performance was poor. An intermediate example was given by the November 1988 Carraixet event, where, for an intermediate magnitude event, even when a delay time between the inputs and outputs of 30 min was used, the results were no better than mediocre (Figure 2)

\section{ASSESSMENT OF FORECASTING PERFORMANCE}

\section{Event-based forecast performance assessment}

The performance of the TFMs for both test catchments has been assessed using a small number of events (Table III). Owing to sparsity of historic data, the magnitude of the events varied greatly-however, this provided an opportunity to investigate the relationship between model forecasting performance and event magnitude. It should be noted that the test events were not used to calibrate the model and therefore provide an unbiased test of model forecasting performance.

The study indicates that the model performed well for both catchments when the TFM, calibrated using a single high-magnitude event, was used to forecast the hydrographs of a lower magnitude event. This is illustrated with two examples: the Rambla de Poyo model for a (low magnitude) test event (April 1991) and the Carraixet model for the (intermediate magnitude) November 1988 event. Figures 4 and 5 present the forecast performance for these two events.

Table III. Event-based forecast

\begin{tabular}{|c|c|c|c|c|}
\hline Basin & $\begin{array}{l}\text { Event used for } \\
\text { calibrating model }\end{array}$ & $\begin{array}{l}\text { Event used for } \\
\text { simulation }\end{array}$ & Delta factor & $\begin{array}{c}\text { Forecast root mean } \\
\text { square errors (RMSE) }\end{array}$ \\
\hline Barranc de Carraixet & $\begin{array}{l}\text { November } 1988 \\
\text { September } 1990 \\
\text { September } 1990\end{array}$ & $\begin{array}{c}\text { September } 1990 \\
\text { November } 1988 \\
\text { April } 1991\end{array}$ & $\begin{array}{l}1 \cdot 1 \\
1 \cdot 11\end{array}$ & $\begin{array}{l}2.397 \\
1.076 \\
0.909\end{array}$ \\
\hline Rambla de Poyo & $\begin{array}{l}\text { November } 1988 \\
\quad \text { April } 1991\end{array}$ & $\begin{array}{c}\text { April } 1991 \\
\text { November } 1988\end{array}$ & $\begin{array}{l}0.45 \\
0.97\end{array}$ & $\begin{array}{r}2 \cdot 196 \\
23 \cdot 345\end{array}$ \\
\hline
\end{tabular}

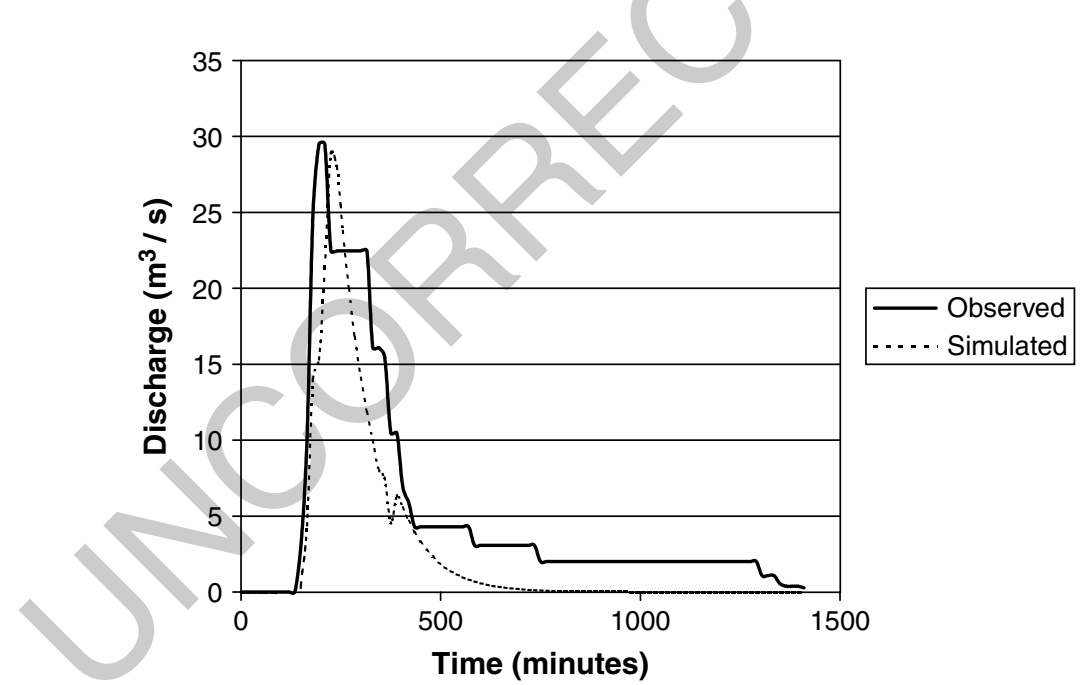

Figure 4. Example of temporal extrapolation of the model in a fast-response catchment (Poyo): simulation of a low magnitude event (April 1991), using the TFM calibrated for a high-magnitude event (November 1988). Error in peak estimation: $2 \%$ in peak discharge and 30 min out of phase 


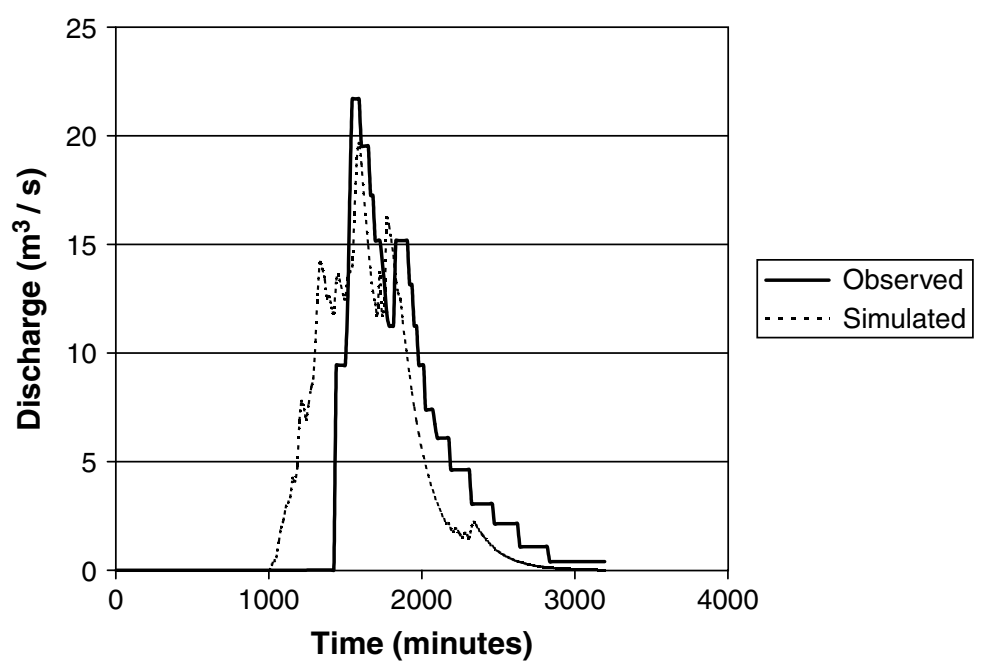

Figure 5. Example of temporal extrapolation of the model in a slow-response catchment (Carraixet): simulation of a medium magnitude event (November 1988), using the TFM calibrated for a high-magnitude event (September 1990). Error in peak estimation: $9.4 \%$ in peak discharge and $45 \mathrm{~min}$ out of phase

It is interesting to note that for both catchment models, forecasting performance is poor when the model is used to forecast flows for a high-magnitude event when the models have been calibrated using a lower magnitude events. This is illustrated by two examples: the Poyo catchment model for the (high magnitude) November 1988 event, and the Carraixet catchment model for the (high magnitude) September 1991 event. These are shown in Figures 6 and 7.

\section{Spatial model transposition}

The forecasting of flows in ungauged catchments represents a significant challenge. In order to investigate the potential of the TFM for forecasting flows in such circumstances, the forecasting performance of a TFM

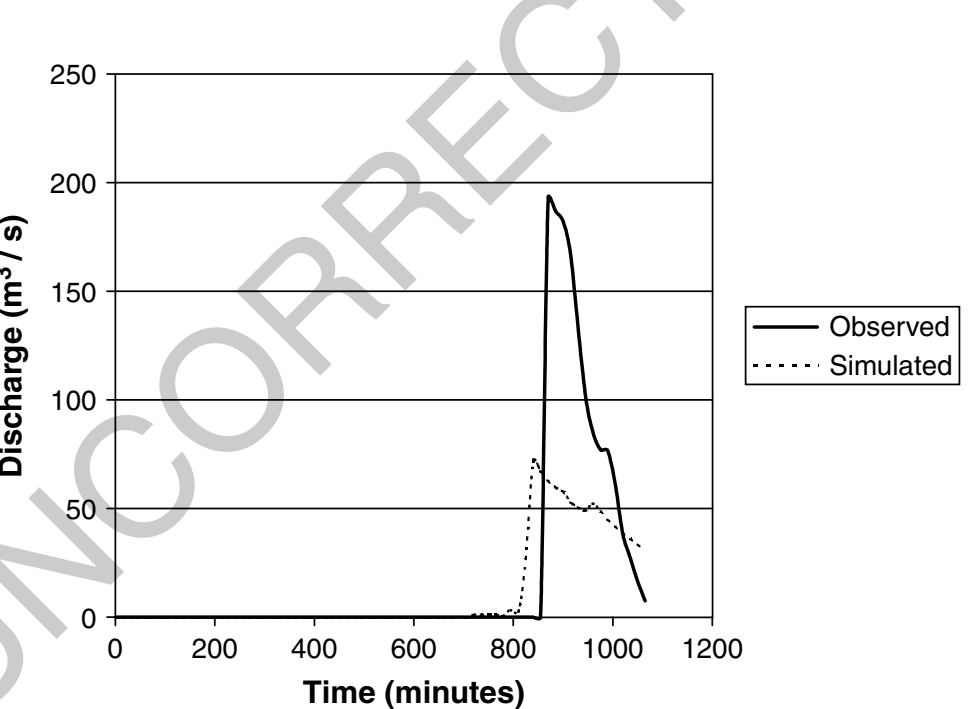

Figure 6. Example of temporal extrapolation of the model in a fast-response catchment (Poyo): simulation of a high-magnitude event (November 1988), using the TFM calibrated for a low-magnitude event (April 1991). Error in peak estimation: $62.7 \%$ in peak discharge and $30 \mathrm{~min}$ out of phase 


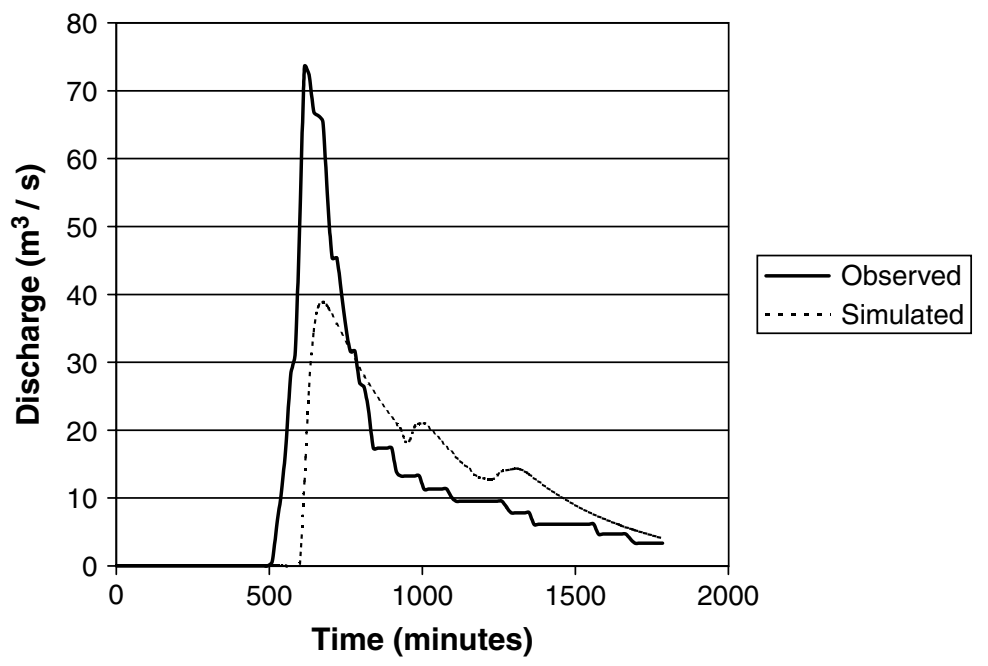

Figure 7. Example of temporal extrapolation of the model in a slow-response catchment (Carraixet): simulation of a high-magnitude event (September 1990), using the TFM calibrated for a medium magnitude event (November 1988). Error in peak estimation: 47\% in peak discharge and $60 \mathrm{~min}$ out of phase

calibrated using data in a gauged ('donor') catchment was assessed when applied to a second ('receptor') catchment. For the purposes of this investigation, the receptor was also gauged-providing the opportunity to assess the quality of the model forecasts. The same two test catchments were used for this study (Poyo and Carraixet). Both catchments (donor and receptor) belong to the same environment, having the same geological structure and very similar geomorphological features. They are located just to the north and to the south of the city of Valencia, so they are very close and they are affected by the same storms. The only difference is the speed of the basin response to the rainfall, derived from their different permeability and slope. The model has been tested for different impulse-response functions, fitted in different events, as can be seen in Table IV.

The assessment reveals the rate of catchment response to storm rainfall as a key factor in the quality of model forecasting performance in the receptor catchment. The TFMs calibrated in the fast response Poyo catchment produced good quality forecasts when applied to the slower response Carraixet catchment, even when a low-magnitude event had been used to calibrate the model in the fast basin. This was highlighted by the simulation carried out on the Carraixet September 1990 event, using the TFM calibrated for the Poyo April 1991 event. Figure 8 illustrates how the model calibrated for the fast response catchment, even during a low-energy event such as that of April 1991, could be extrapolated to a slower response catchment, provided the simulated event had a certain magnitude. It is thought that this is because high-magnitude events in the receptor catchment reduce the importance of physical catchment processes in runoff generation, leading to good model performance.

Table IV. Spatial model transposition

\begin{tabular}{|c|c|c|c|c|c|}
\hline \multicolumn{2}{|c|}{ Calibration } & \multicolumn{2}{|c|}{ Simulation } & \multirow{2}{*}{$\begin{array}{l}\text { Delta } \\
\text { factor }\end{array}$} & \multirow{2}{*}{$\begin{array}{l}\text { Forecast root } \\
\text { mean square } \\
\text { errors (RMSE) }\end{array}$} \\
\hline Donor basin & Event & Receptor basin & Event & & \\
\hline Barranco de Carraixet & September 1990 & Rambla de Poyo & November 1988 & $1 \cdot 1$ & $18 \cdot 547$ \\
\hline Rambla de Poyo & November 1988 & Barranc de Carraixet & September 1990 & $0 \cdot 28$ & 4.626 \\
\hline Rambla de Poyo & April 1991 & Barranc de Carraixet & September 1990 & $0 \cdot 7$ & $4 \cdot 368$ \\
\hline
\end{tabular}


2

3

4

5

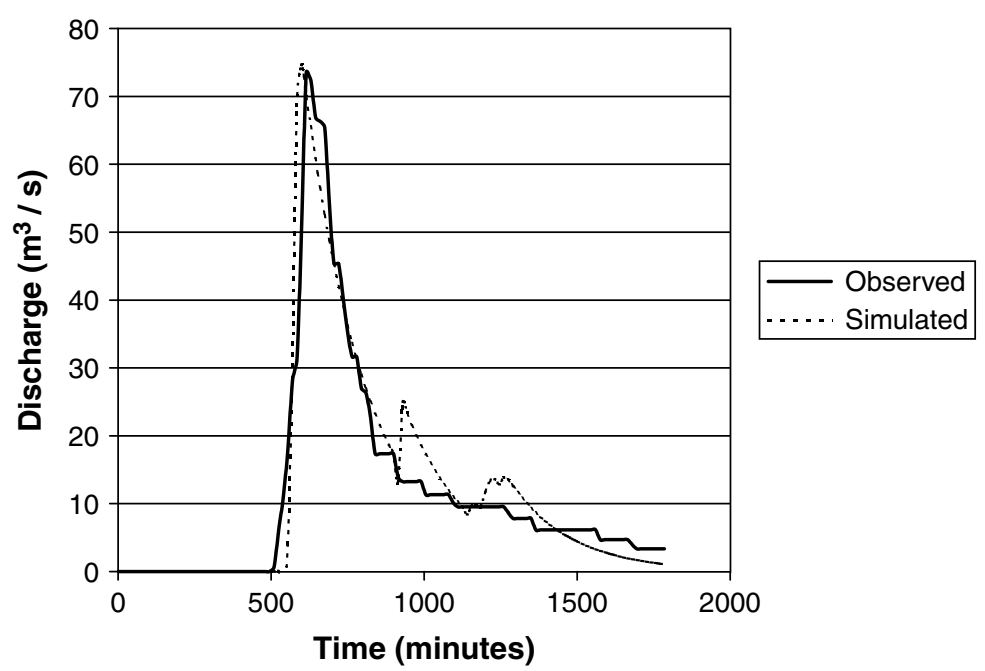

Figure 8. Example of areal extrapolation from a donor fast catchment to a receptor slow catchment: simulation of September 1990 in Carraxiet, using the TFM calibrated in Poyo, for the April 1991 event. Error in peak estimation: 1.56\% in peak discharge and 15 min out of phase

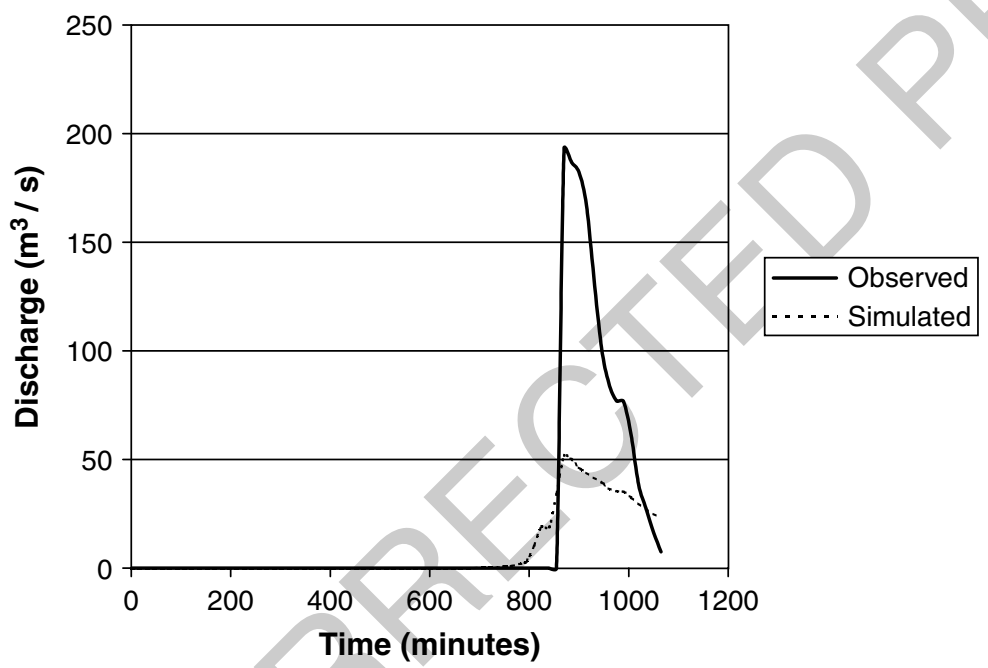

Figure 9. Example of areal extrapolation from a donor slow catchment to a receptor fast catchment: simulation of November 1988 in Poyo, using the TFM calibrated in Carraixet, for the September 1990 event. Error in peak estimation: $51.71 \%$ in peak discharge and 0 min out of phase

Conversely, application of the TFM calibrated for the slower response Carraixet catchment when applied to the faster response Poyo catchment performed poorly for all events. Figure 9 shows, as an example, the simulation of the November 1988 event in the Rambla de Poyo, using the TFM calibrated for the Carraixet event of September 1990.

\section{CONCLUSIONS AND DISCUSSION OF RESULTS}

Although the results of this work are only preliminary, the various simulations have demonstrated the potential of the TFM for rainfall-runoff modelling in Mediterranean catchments. Other simulations were carried out in 
these catchments for the same events (Camarasa, 1995), using the geomorphological unit hydrograph (GUH) developed by Rosso (1984) and based on the Nash (1954) • unit hydrograph. This model uses morphometric characteristics of the basin to estimate the scale and the form parameters of the classic Nash unit hydrograph. Results of simulations showed the important role of the scale parameter (in comparison to the form parameter), related to rainfall intensity and structure, as well as the speed of quickflow. The form parameter, related to basin morphology, had less influence on the prediction of the final hydrograph (Camarasa, 1995).

In these catchments, which lack baseflow and subsurface regulating inputs, the quickflow depends almost exclusively on the rainfall. When the floods are of lower magnitude, the influence of the catchment on the processes of runoff dominates, and the dependence on the rainfall is reduced. In such cases it was more difficult to reproduce the hydrographs using simple linear TFMs. However, when high-magnitude events are considered, the influence of the catchment is minimized, the dependence on the rainfall increases considerably and model performance improves significantly. Simulation performance improves markedly when an input of effective rainfall is used. The estimation of effective rainfall, which is of primary importance in any semi-arid catchment, has been shown to be undertaken more effectively using an empirical model such as that of the Soil Conservation Service, rather than a simple linear method scaling approach as used by the TFM.

The response rate of the catchment also has been shown to be a very important factor in the forecasting performance of the TFM. Although both catchments have similar features and are located in the same morphoclimatic environment, the rainfall-runoff conversion processes in the Poyo River are faster than in the Carraixet River, owing to differences in permeability and slope. The lithology of the Poyo basin produces a lower permeability compared with the Carraixet basin. Slope is greater in the Poyo basin than in the Carraixet basin. Consequently, for similar inputs, the Poyo basin hydrograph shows shorter lag-time ( $3 \mathrm{~h}$ compared with $5 \mathrm{~h}$ in Carraixet) and time to peak. The shorter the runoff time, the less the influence of the catchment on the hydrograph. That is why the Poyo hydrograph reproduces better the rainfall structure and, consequently, the TFM is able to simulate this hydrograph better than for the Carraixet. Overall, model performance was best for the faster responding Poyo catchment than in the slower response Carraixet. In the latter, the influence of the physical catchment processes increases and, consequently, the results of the simulations were not as convincing.

The TFM was most effective when calibrated on high-magnitude events or, in the case of model transposition, from a fast response donor catchment. Once again, the study highlighted the importance of the rainfall as a factor in model performance, observations that are consistent with the statement of Graf (1988) that 'processes dominate forms', and the catchment's response reproduces, in a purer manner, the system's inputs. The model could capture this type of response, which some authors, referring to the unit hydrograph, have called 'the catchment's finger print' (Marco and Reyes, 1981).

This is not the case, however, for low-magnitude events, or for slow response catchments, where the output hydrograph reflects much more the influence of the catchment processes, the process 'noise" reducing the models performance.

The results suggest that there is considerable potential for the use of a simple linear rainfall-runoff transferfunction model for real-time flood forecasting in Mediterranean environments. The findings indicate that the most important factor in producing satisfactory forecasting performance is to ensure that the models are calibrated using high-magnitude flow events. If transposition of a calibrated model to an ungauged catchment is necessary, the most important issue is to ensure that the donor catchment is a faster response system than the receptor catchment. The greatest errors have been observed to occur when forecasting low-magnitude events in slow response catchments: this is of limited consequence in a flood forecasting and warning context.

\section{ACKNOWLEDGEMENTS}

This work has been financed by the University of Alcalá. The authors wish to thank the Telford Research Institute of Environment Systems (University of Salford) for the technical assistance to carry out the 
1 simulations. The hydrological data were kindly provided by the Jucar Hydraulic Authority (Confederación 2 Hidrográfica del Júcar).

\section{REFERENCES}

Abdulrazzak MJ, Sorman AU, Alhames AS. 1989. Water balance approach under extreme arid conditions: a case study of Tabalah basin, Saudi Arabia. Hydrological Processes 3: 107-122.

Aucott LM, Grigg WL, Han D, Cluckie ID. 1992. Developing applications of weather radar in the Wessex flood forecasting system. Proceedings 2nd International Symposium on Hydrological Applications of Weather Radar, University of Hanover, September.

Birks C, Bootman A, Cluckie ID, Han D. 1989. Wessex flood forecasting system. In Hydrological Applications of Weather Radar, Cluckie ID, Collier CG (eds). Ellis-Horwood: Chichester.•

Bobinski E, Mierkiewicz M. 1986. Recent developments in simple adaptive flow forecasting models in Poland. Hydrological Sciences Journal 31: 297-320.

Box GEP, Jenkins GM. 1976. Time Series Analysis: Forecasting and Control. Prentice-Hall.•

Camarasa AM. 1995. Génesis de crecidas en pequeñas cuencas semiáridas: Barranc del Carraixet y Rambla de Poyo. PhD thesis, MOPTConfederación Hidrográfica del Júcar, Valencia, 252 pp.

Camarasa AM, García Bartual R. 1991. Estimación del hidrograma de crecida a partir de un modelo conceptual de base geomorfológica. Tecnología del Agua 49-55.•

Chander S, Shanker H. 1984. Unit hydrograph based forecast model. Hydrological Sciences Journal 31: 279-291.

Cluckie ID. 1993. Real-time flood forecasting using weather radar. In Concise Encyclopedia of Environmental Systems, Young PC (ed.). Pergammon Press: Oxford.

Cluckie ID, Harpin R. 1982. A real-time simulator of the rainfall-runoff process. Mathematics and Computers in Simulation XXIV: 131-139.

Cluckie ID, Owens M. 1987. Real-time rainfall-runoff models and use of weather radar information. In Weather Radar and Flood Forecasting, Collinge VK, Kirby C (eds). Wiley: Chichester; 171-190.

Cluckie ID, Harwood DA, Harpin R. 1980. Three systems approaches to real-time rainfall-runoff forecasting. In Hydrological Forecasting. Proceedings of the Oxford Symposium, April, IAHS Publication 129, International Association of Hydrological Sciences: Wallingford; 389-396.

Cluckie ID, Yu PS, Tilford KA. 1989. Real-time flood forecasting, model structure and data resolution. In Weather Radar Networking, Collier CG, Chapius M (eds). Proceedings, COST-73 Seminar on Weather Radar Networking, Brussels, Belgium, September. Kluwer: Dordrecht; 459-472.

Corradini C, Melone F. 1987. On the structure of a semi-distributed adaptive model for flood forecasting. Hydrological Sciences Journal 32(2): 227-242.

Corradini C, Melone F, Ubertini L, Dingh UP. 1986. Geomorphologic approach to synthesis of direct runoff hydrograph from the upper Tiber basin. In Scale Problems in Hydrology. Kluwer: Dordrecht; • 57-79.

García Bartual R, Marco J. 1990. A stochastic model of the internal structure of convective precipitation in time at a raingauge site. Journal of Hydrology 118: 129-142.

Graf WL. 1988. Fluvial Processes in Dryland Rivers. Springer-Verlag: Berlin.

Gupta VK, Waymire E. 1983. On the formulation of an analytical approach to hydrologic response and similarity at the basin scale. Journal of Hydrology 65: 95-123.

Harpin R. 1982. Real time flood routing with particular emphasis on linear methods and recursive estimation techniques. PhD thesis, University of Birmingham, Department of Civil Engineering.

Isermann R. 1981. Digital Control Systems, Springer-Verlag: Berlin; 566 pp.

Jakeman AJ, Hornberger GM. 1993. How much complexity is warranted in a rainfall-runoff model? Water Resources Research 29(8): $2637-2649$.

Klemes V. 1981. Stochastic models of rainfall-runoff relationships. Pre-symposium proceedings, International Symposium of Rainfall-Runoff Modelling; • 36-36.

Lees MJ. 1997. Modelling and automatic control of flow regulation for multipurpose catchment management. Proceedings, 5th British Hydrological Society National Hydrology Symposium, Salford; 1.1-1.12.•

Lees MJ, Young PC, Ferguson S, Beven K, Burns J. 1994. An adaptive flood warning scheme for the River Nith at Dumfries. In 2nd International Conference on River Flood Hydraulics, White WR, Watts J (eds). Hydraulics Research; Wallingford. Wiley: Chichester.• Maidment DR. 1993. Developing a spatially distributed unit hydrograph by using GIS. In Application of Geographic Information Systems in Hydrology and Water Management $\bullet$ IAHS 211, International Association of Hydrological Sciences: Wallingford; 181-192.

Marco J. 1989. La defensa integral frente a las crecidas en la Comunidad Valenciana. In El agua en la Comunidad Valenciana. Universidad Politécnica de Valencia; 61-69.

Marco J, Reyes M. 1981. Hidrología. Escuela técnica Superior de ingenieros de caminos, canales y puertos de Valencia.

Mateu JF. 1988. Crecidas e inundaciones en el País Valenciano. In Guía de la Naturaleza de la Comunidad Valenciana. Edicions Alfons el Magnànim: Diputacion Provincial de Valencia; 595-636.

Moore RJ. 1980. Real-time Forecasting of Flood Events using Transfer Function Noise Models. Part 2. Contract Report to the Water Research Centre, Medmenham, UK. Institute of Hydrology, Wallingford.

Moore RJ, O'Connell PE. 1978. Real-time Forecasting of Flood Events using Transfer Function Noise Model. Part 1. Contract Report to the Water Research Centre, Medmenham, UK. Institute of Hydrology, Wallingford.

Morisawa M. 1985. Rivers: Form and Process. Longman: London.

Nalbantis I. 1995. Use of multiple time-step information in rainfall-runoff modelling. Journal of Hydrology 165: 135-159. 
1 Nash JE. 1958. Determining runoff from rainfall. Institute of Civil Engineering Proceedings 10: 163-184.

2 Nouh M. 1990. Flood hydrograph estimation from arid catchment morphology. Hydrological Processes 4: 103-120.

O’Connell PE, Clark RT. 1981. Adaptive hydrological forecasting - a review. Hydrological Sciences Bulletin 26(2): $179 \mathrm{pp}$.

Owens MD. 1986. Real-time flood forecasting using weather radar data. PhD thesis, University of Birmingham, Department of Civil Engineering.

Powell SM. 1985. River basin models for operational forecasting of flow in real-time. PhD thesis, University of Birmingham, Department of Civil Engineering.

Powell SM, Cluckie ID. 1984. On the sampling interval of discrete transfer function models of the rainfall runoff process. Proceedings 7 th IFAC/IFOR Symposium on Identification and System Parameter Estimation.

Ramos J, Mallants D, Feyan J. 1995. State-space identification of linear deterministic rainfall-runoff models. Water Resources Research 31(6): 1519-1531.

Reed DW. 1984. A Review of British Flood Forecasting Practice. Report No. 90, Institute of Hydrology 42 pp.•

10 Rodriguez-Iturbe I, Valdés JB. 1979. The geomorphological structure of hydrologic response. Water Resources Research 15(6): $1409-1420$.

11 Rodriguez-Iturbe I, Gonzalez Sanabria M, Bras RL. 1982. The geomorphoclimatic theory of the instantaneous unit hydrograph. Water Resource Research 18(4): 877-886.

Rosso R, Caroni E. 1987. Analysis estimation and prediction of the hydrologic response from catchment geomorphology. Memorie e studi dell'istituto di idraulica e costruzioni idrauliche del politecnico di milano 1: 93-108.

Rosso R. 1984. Nash model relation to Horton order ratios. Water Resources Research 914-920.

Segura FS. 1990. Las ramblas valencianas. PhD thesis, Universitat de València, $229 \mathrm{pp}$

Segura FS, Camarasa A. 1996. Balances hídricos de crecidas en ramblas mediterráneas: pérdidas hídricas. In Clima y agua: la gestión de un recurso climático, Marzol MV, Dorta P, Valladares P (eds). Universidad de La Laguna: Tenerife; 235-245.

17 Sherman LK. 1932. Streamflow from rainfall by unitgraph method. Engineering New Records 103: 501-505.

18 Témez J. 1978. Cálculo hidrometeorológico de caudales máximos en pequeñas cuencas naturales. MOPU Dirección General de Carreteras, 113 pp.•

19 Tilford KA. 1993. Weather radar data for operational hydrology. PhD thesis, Telford Institute of Environmental Systems, Department of Civil and Environmental Engineering, University of Salford, Manchester, $330 \mathrm{pp}$.

US Soil Conservation Service. 1972. National Engineering Handbook, Section 4, Supplement A, Hydrology. US SCS: Wäshington, DC.

Wilke K, Barth F. 1991. Operational river-flood forecasting by Wiener and Kalman filtering. In Hydrology for the Water Management of Large River Basin. Vienna Symposium. IAHS Publication 201, International Association of Hydrological Sciences: Wallingford. • Woolhiser DA. 1971. Deterministic approach to watershed modelling. Nordic Hydrology II •146-166.

Young PC, Beven KJ. 1994. Data-based mechanistic modelling and the rainfall-flow non-linearity. Environmetrics 5: 335-363. 


\section{QUERIES TO BE ANSWERED BY AUTHOR (SEE MARGINAL MARKS)}

IMPORTANT NOTE: Please mark your corrections and answers to these queries directly onto the proof at the relevant place. Do NOT mark your corrections on this query sheet.

\begin{tabular}{ll}
\hline Query No. & Query \\
\hline Q1 & Is 'germanic' the correct word? \\
Q2 & Explain subscripts p \& q \\
Q3 & Nash 1954 not listed in refs \\
Q4 & Inclusive page range of article \\
Q5 & location of publishers? \\
Q6 & Vol no? \\
Q7 & Names of the ed(s)? \\
Q8 & Venue \& date (e.g 1 May)? pp correct \\
Q9 & Date (e.g 1 may)? \\
Q10 & Inclusive pp? \\
Q11 & Name(s) of ed(s) \\
Q12 & Location of I.H? \\
Q14 & Location of MOPU \\
Q15 & Inclusive page range and name(s0 of ed(s)? \\
\hline
\end{tabular}

